\title{
VARIABILITY OF SEDIMENT TRANSPORT IN THE SCOTT RIVER CATCHMENT (SVALBARD) DURING THE HYDROLOGICALLY ACTIVE SEASON OF 2009
}

\author{
Waldemar Kociuba, GrZegorz Janicki, Krzysztof Siwek \\ Faculty of Earth Sciences and Spatial Management, Maria Curie-Skłodowska University in Lublin, Poland
}

Manuscript received: February 12, 2014

Revised version: February 17, 2014

\begin{abstract}
Kociuba W., JANICKI G., SiWEK K., 2014. Variability of sediment transport in the Scott River catchment (Svalbard) during the hydrologically active season of 2009. Quaestiones Geographicae 33(1), Bogucki Wydawnictwo Naukowe, Poznań, pp. 39-49, 6 figs, 1 table. DOI 10.2478/quageo-2014-0011, ISSN 0137-477X

ABSTRACT: Investigations of fluvial transport in the glacial river catchment (Scott River, Spitsbergen) were conducted in the melt season of 2009. A special attention was given to dynamics and distribution of bedload transport - the major component of fluvial transport in a proglacial gravel-bed river. Bed-load transport rate was determined using the River Bedload Traps (RBT) constructed for the project's need. The obtained results indicate high diversity of bedload transport, the amount of which reached up to $220 \mathrm{~kg} \mathrm{~m}^{-1}$ day-1 for twenty-four hours in particular measurement sites. The results confirmed also great variability of local intensity fluvial processes in polar zone.
\end{abstract}

KEY wORDS: glacial catchment, channel system, bedload transport, Spitsbergen

Address of the corresponding author: Waldemar Kociuba, Faculty of Earth Sciences and Spatial Management, Maria CurieSkłodowska University in Lublin, Kraśnicka 2CD, 20-718 Lublin, Poland, e-mail: waldemar.kociuba@poczta.umcs.lublin.pl

\section{Introduction}

In conditions with little anthropopression, similar to the nature of subpolar zone in the European sector of the Arctic, the type and amount of material transported by rivers is the outcome of geomorphological processes occurring in the catchment and river channel. Therefore, the lack of anthropogenic components facilitates the analysis of fluvial system functioning, and rivers in this region are natural and rather sensitive indicators of modern global climate changes. A good example of such geosystem functioning is the catchment of the Scott River located in the NW part of the Wedel Jarlsberg Land, Calypsobyen region, Spitsbergen (Fig. 1). Multi-annual research conducted in this catchment indicated a close relationship between proglacial outflow and observed climatic changes (Bartoszewski et al. 2007) and concerned mostly the hydrological regime of the Scott River (Harasimiuk, Król 1993, Bartoszewski et al. 2007, 2013, Chmiel et al. 2007, Zagórski et al. 2007). However, the former investigations of fluvial transport in the Scott River catchment (NW Spitsbergen) and in the Petunia Bukta region (Central Spitsbergen) included analysis of solution and suspension transport, without the measurements of bed load material transport (Kostrzewski et al. 1989, Rachlewicz 2007, Szpikowski et al. 2014) the main component of transport in gravel-bed rivers (Hammer, Smith 1983, Warburton 1990). Therefore, determination of the elementary value of bed load concentration became an impor- 


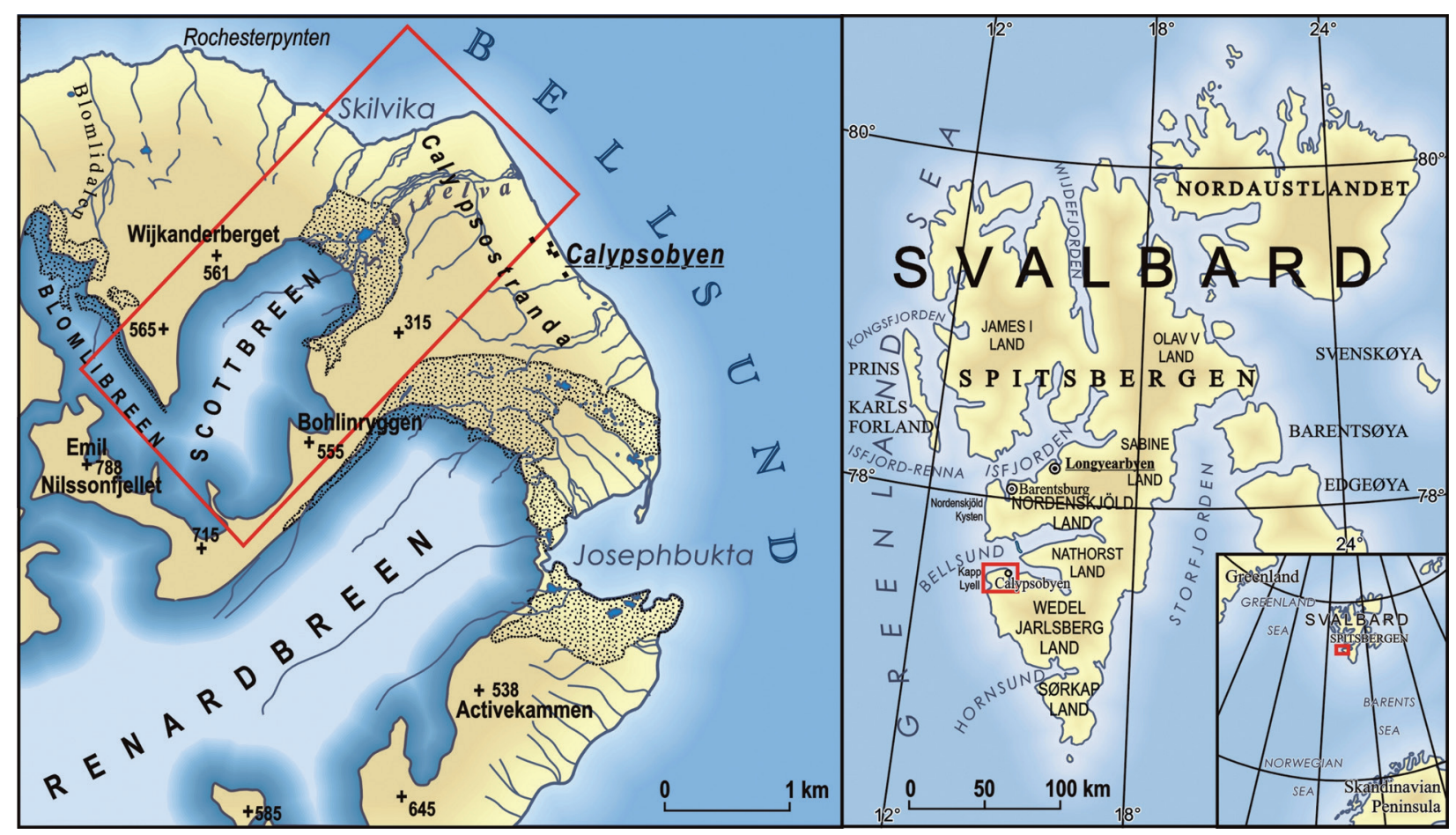

Fig. 1. Localisation of the research area

tant research objective. In this paper we present the primary results of the research initiated in 2009 on the variability of bedload transport in the environment of a gravel-bed river in the subpolar zone in the SW Spitsbergen.

This research concerned the functioning of the Scott River catchment with the predominant glacial hydrological regime, typical of the subpolar zone (Bartoszewski 1998, Rachlewicz 2007, Rachlewicz et al. 2007, Zwoliński et al. 2007, Beylich et al. 2010). Discharge rate is the main factor conditioning the dynamics of fluvial processes in the described catchment. It mostly depends on the rate of glacial ablation, which is the main alimentation source for the river $(90 \%)$. The river is also supplied with rainfall $(4 \%)$, nival $(4 \%)$ and permafrost (about $2 \%$ ) waters. The contribution of the latter is limited by the permafrost active layer (Bartoszewski 1998). An important factor determining fluvial transport is also morphology of slopes, valleys' floors and rivers' channels, which influences sediment grain size, amount of transported sediment and bedload transport rate (Kociuba et al. 2010, Kociuba, Janicki 2013).

\section{Study area}

The analysed catchment of the Scott River, situated on the Bellsund Bay in the south-western part of the Wedel Jarlsberg Land (SW Spitsbergen), is about $10 \mathrm{~km}^{2}$ in area. More than half of the catchment $(57 \%)$ is covered by the Scott Glacier, which is at the stage of strong recession. This valley glacier is less than $4 \mathrm{~km}$ long and from 1.1 to $1.8 \mathrm{~km}$ wide (Fig. 2). Its highest parts reach 600 $\mathrm{m}$ a.s.l, and the front is at $90 \mathrm{~m}$ a.s.l. The main relief element of the upper part of the catchment is a glaciated mountain valley, surrounded amphitheatrically by slopes of mountains rising to $700 \mathrm{~m}$ a.s.l. The slopes, composed of Proterozoic metamorphic rocks (tillites, phyllites and quartzites), are usually steep rock walls (massive, rocky slopes) modelled by weathering, nival and mass movement processes. The upper part of such a slope is of erosional nature, with developed corrasion troughs forming incisions in places. The lower, accumulation section is formed by a steep talus fan. The corrosion troughs are separated by steep rock ridges.

The front zone of the Scott Glacier is characterized by the occurrence of different relief forms: glaciogenic (frontal, lateral, and ablation mo- 
raines, roches moutonnée), glaciofluvial (internal sandurs, marginal lakes), and also nival (nival moraines) (Fig. 2). In this part of the catchment the dynamics of morphogenetic processes has been the highest as a result of fast movements of the glacier front after the end of the Little Ice Age. The observed recession and flattening of the ice front was discontinuous in the 1960s when the glacier advance (through surges) left push moraines.
Since then the glacier front has retreated again at a rate of $6 \mathrm{~m} \mathrm{y}^{-1}$ in the 1960s and 1970s, to a maximum $15 \mathrm{~m} \mathrm{y}^{-1}$ in the 1990s, and about $20 \mathrm{~m} \mathrm{y}^{-1}$ in recent years (2005-2006) (Zagórski et al. 2008).

Subglacial outflow, which concentrates the drainage of glacial waters, occurs in the central part of the glacier front, and from there water flows through the internal sandur system to small marginal lakes, which are the main source

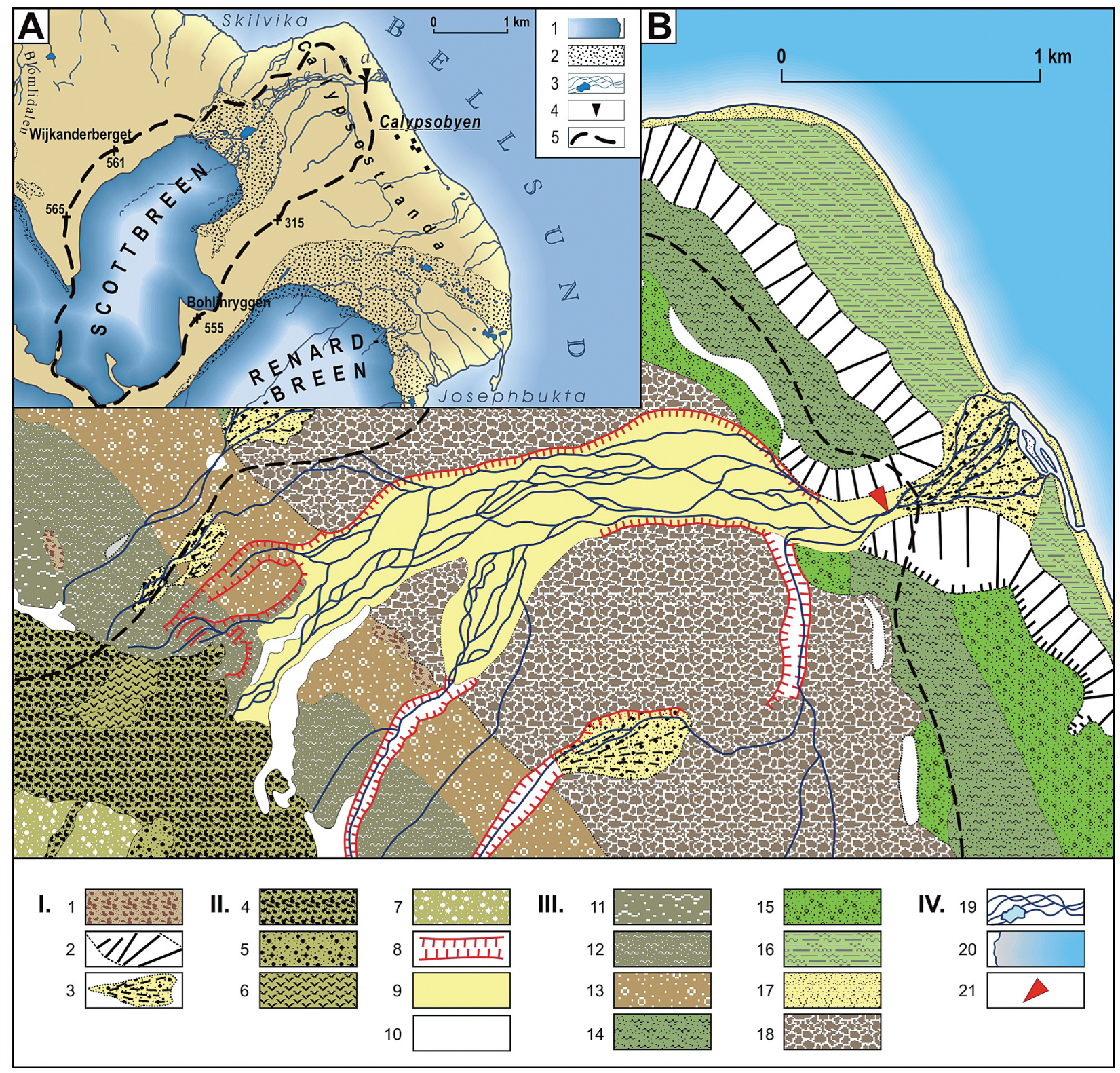

Fig. 2. [A] Situation of the Scott River catchment: 1. valley glaciers, 2. glacial accumulation zones, 3. rivers and water bodies, 4. location of river gauge, 5. border of catchment; [B] geological-morphological conditions after Szczęsny et al. (1987): I. slope landforms: 1. rock outliers, 2. morphological edges, 3. alluvial fans; II. glacial and nival landforms: 4. terminal and lateral ice-cored moraine, 5. medial moraine, 6. solifluction covers, 7. ablation moraine, 8. scarps and slopes of valley, 9. extramorainal sandur, 10. snow patches; III. marine terraces with structural features: $11.100-130 \mathrm{~m}$ a.s.1., 12 . $70-80 \mathrm{~m}$ a.s.1., 13. 50-60 m a.s.l., 14. 35-45 m a.s.l., 15. 18-30 m a.s.l., 16. 1-6 $\mathrm{m}$ a.s.l., 17. beach, 18. depressions, IV. Other: 19. rivers and streams, 20. sea, 21. location of research profile 
of the Scott River. The river flows through the gorge of the frontal moraine on the external sandur surface where it forms a wide braided system in the non-glaciated part of the valley. The Scott River has several small tributaries supplied with snow-permafrost waters, and the greatest of them is the Renifer Stream draining the eastern part of the sandur (Bartoszewski 1998). The occurrence of varying age and situation of layers of sandur in the extramarginal zone of the Scott Glacier indicates a great variability of the glacier front and outflows from the glacier snouts. The oldest layers are flat and diversified by the channels of former proglacial streams. The youngest sandur layer occurring in the ice-moraine ridge at the glacier snout is formed by a braided river system with a variable channel pattern. In the proximal part of the sandur the Scott River is characterized by great morphologic effectiveness and transports great amounts of mineral material. The coarser fraction is accumulated as interchannel longitudinal bars, and finer fractions are redeposited in a rather narrow zone of the valley sandur and transported to the fiord (Reder 2006).

The non-glaciated part of the Scott River catchment includes the shore plain called Calypsostranda, which consists of the raised marine terraces. Terrace IV (30-40 $\mathrm{m}$ a.s.1.) is the youngest unit of this system, and the oldest is terrace VIII (105-120 m a.s.l. (Reder, Zagórski 2007). The bedrock of Calypsostranda is composed of Mesozoic deposits: gypsum, dolomite, sandstone, shale and mudstone. They are covered with Cainozoic deposits, which are exposed in the erosion gorge cutting terrace IV and form palaeoskerries occurring on the plain (Fig. 2). These are mostly the Tertiary sandstones with hard coal inserts and the Quaternary marine (gravel, sand and clay) and glacial (till) deposits. The thickness of the Quaternary deposits varies from several metres to a dozen or so metres (Pękala, Repelewska-Pękalowa 1990).

In the middle part of the catchment, within the external sandur, the slopes composed of marine deposits (mostly gravel) are modelled by cryogenic and solifluction processes. The slopes are mainly flat, gently inclined surface merging into valleys' floors without a visible borderline. Only the slopes of the main valley are erosion scarps cut by shallow erosion dissections.
In its lower reaches the Scott River forms the gorge dissecting the marine terrace III (18-30 m a.s.l.) and IV (30-40 $\mathrm{m}$ a.s.l.). In this section of the valley - several dozen metres long - the braided channels join up into one, and farther downstream a system of alluvial fans occurs, which closely adjoins the Recherche fiord (Fig. 2). The river mouth is separated from the bay by the storm ridge, and water flows through the crevasse (Superson, Zagórski 2007).

\section{Methods}

Fluvial processes in the Scott River catchment can be analysed in the conditions of small anthropopression. This area is also a valuable object of geomorphological research because hydro-meteorological conditions have been well examined during twenty-year investigations conducted by a team of scientists from the Maria Curie-Skłodowska University (Bartoszewski 1998, Bartoszewski et al. 2004, Bartoszewski et al. 2006). The additional asset is also the proximity of the Calypsobyen research station of the Maria Curie-Skłodowska University that enables stationary and monitoring studies (Fig. 2).

The hydrometric station and the traps for fluvial transport measurements were located on the Scott River, $350 \mathrm{~m}$ from its mouth, in the middle part of the gorge section (Fig. 2). This location was similar to that of hydrographical monitoring in the previous years (Bartoszewski 1998, Bartoszewski et al. 2004, 2006). The continuous, automatic measurement of river stage was also conducted in this research profile with the use of pressure electronic water gauges recording the variability of water stage every hour. Water samples were taken for analyses of the main physicochemical features (conductivity and suspended sediment concentration). Measurements of water velocity in the cross profile were made using a hydrometric current meter.

Bedload transport was measured using the bedload traps constructed by W. Kociuba (Kociuba et al. 2010). The set of RBT devices was distributed proportionally in the cross-section and anchored to the bottom of the channel (Fig. 3). A similar technical solution (Colorado State University/Forest Service, CSU/FS bedload traps) 


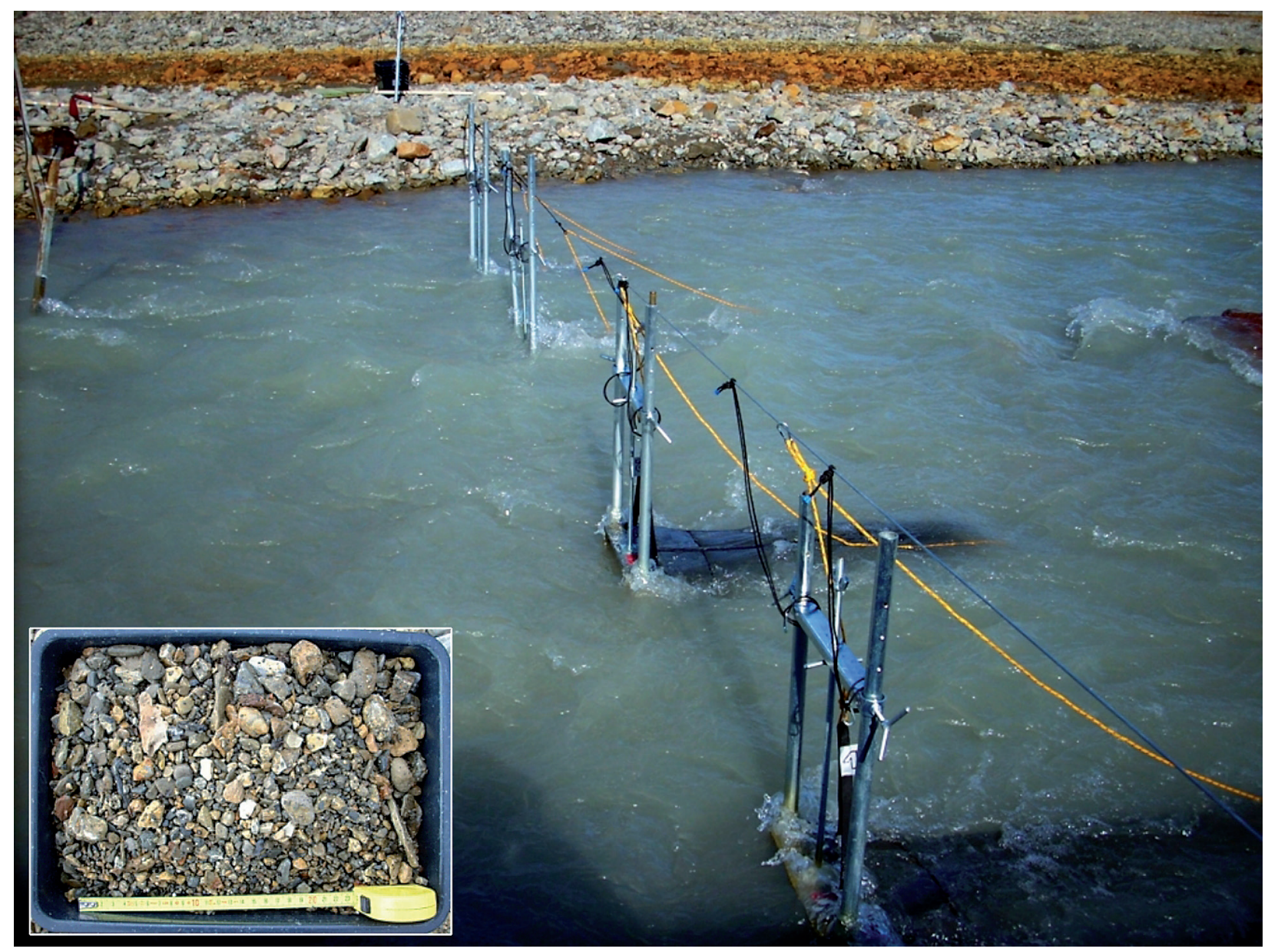

Fig. 3. The set of RBT in the channel cross-profile of the Scott River. Mass of bedload material caught during twenty-four hours in one of measurement sites in the cross-profile of the Scott River

was used by Bunte et al. (2003, 2004), to determine bedload transport rate. According to Bunte and Abt (2009), samplers of the type (e.g. CSU/ FS bedload traps) show high measurement efficiency, and the results obtained describe the relationships between flow velocity and bedload discharge well.

The caught material was weighed and photographed separately for each measurement site every 24 hours (Fig. 3). River sediment transport was measured from July $10^{\text {th }}$ to September $7^{\text {th }}$ of 2009 , i.e. from the time when the whole profile of the river channel emerged from snow-ice cornices on the river banks to the time when the channel bed started to be frozen. In total, 157 samples were taken in 59 measurement days.

The field work included the measurement of directions and intensity of material transport from slope subsystem to channel subsystem. The analyses were conducted in the selected, representative test areas within the slope subsystem and in cross profiles in the channel subsystem. Further works included geomorphological surveys and classification of the permanent and ephemeral macro-, meso- and microforms in the valley and channel. Detailed topographic measurements were made in the selected test areas using laser tachimeter (Nikon DTM-332). The main parameters of valley floor geometry were determined along the selected research profiles. The cubature of the main erosion forms (dissections, erosion troughs and rills) and mapped depositional forms (mostly micro-fans) were measured in the slope subsystem.

The investigations enabled us to determine the degree of coupling between the slope and channel subsystems and to estimate the balance of bed load transported from the analysed river catchment. Erosion-deposition balance in the slope subsystem and the total balance of material transported from the catchment were also estimated. 


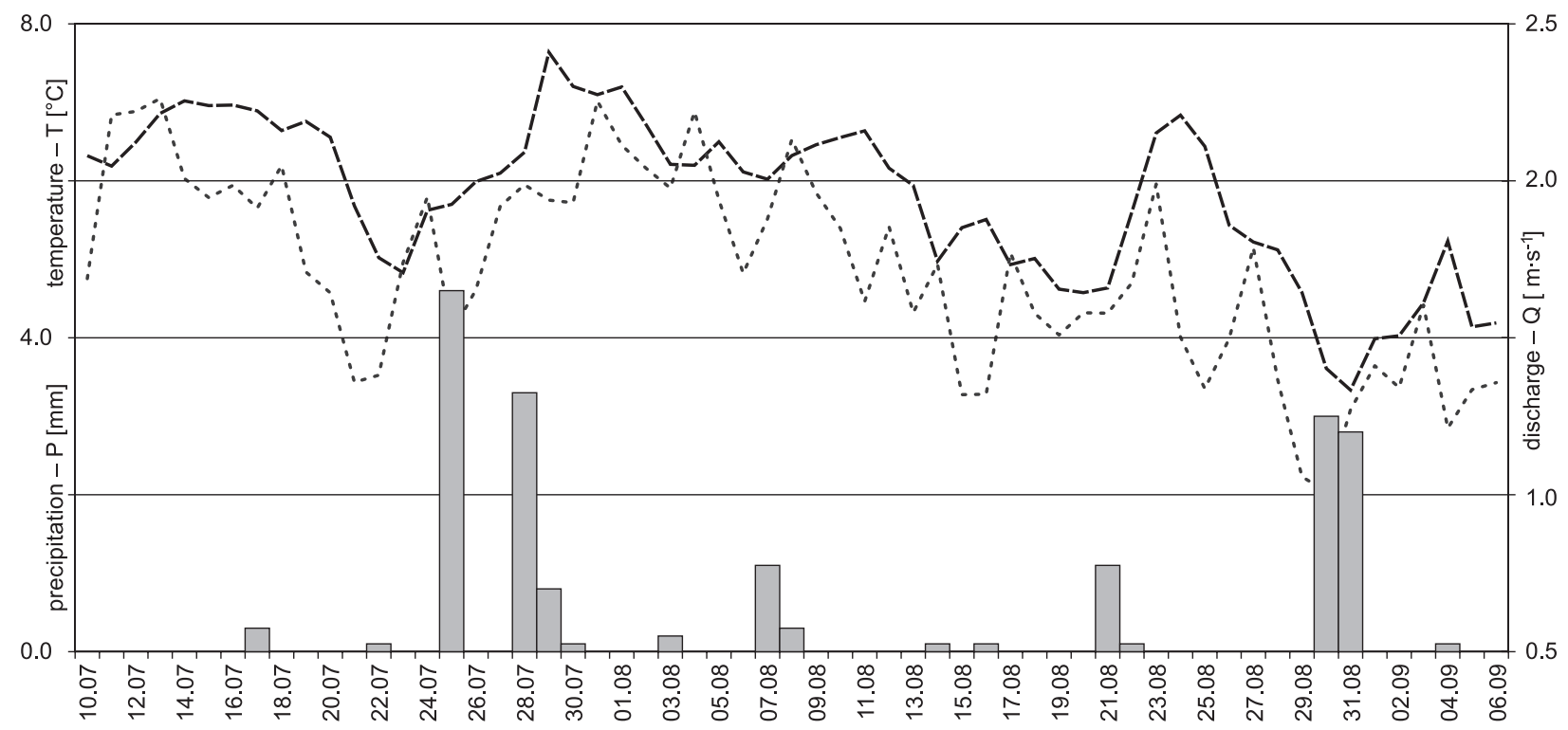

--ー---ー. discharge $-\mathrm{Q}\left[\mathrm{m} \cdot \mathrm{s}^{-1}\right] \quad \ldots \ldots \ldots . .$. temperature $-\mathrm{T}\left[{ }^{\circ} \mathrm{C}\right]$

Fig. 4. Comparison of the run of changes of average daily air temperature and daily precipitation total in the "Calypsobyen" research station of the Maria Curie-Skłodowska University with the average daily discharge in the Scott River in the melt season of 2009: $\mathrm{H}$ - precipitation total, $\mathrm{Q}$ - daily discharge, $\mathrm{T}$ - average daily air temperature

The main meteorological variables such as air temperature and precipitation total, which affect the parameters of discharge and material transport, were recorded every ten minutes by an automatic meteorological station. The station is situated on the Calypsostranda shore plain $(23 \mathrm{~m}$ a.s.l.) covered by patch tundra vegetation, about $200 \mathrm{~m}$ from the Recherche Fiord shore, near the research station of the Maria Curie-Skłodowska University.

\section{Hydro-meteorological conditions of sediment transport in the melt season of 2009 in the Bellsund region}

Weather conditions determining the course of hydrological and geomorphological processes in the Bellsund region are mostly conditioned by cyclone systems connected with the Island centre and the Arctic and Greenland anticyclone systems, which determine the advection nature and type of air masses. These systems are influenced at the local scale by mountain massifs (Bohlinryggen and Wijkanderberget, Fig. 2), water of the Bellsund fiord system and ice covers (Renard and Scott glaciers). Therefore, both ocean-land breeze circulations and catabatic winds occur in the
Bellsund region and contribute to great variability of weather conditions (Gluza, Siwek 2006). This is mostly reflected in temporal and spatial differentiation of air temperature and precipitation total. Topoclimate investigations indicated, among others, considerable differences in monthly precipitation totals between the firn field of the Scott Glacier and Calypsostranda (Bartoszewski 1998).

In the research station of the Maria $\mathrm{Cu}$ rie-Skłodowska University, substantial variability in the air temperature during the melt season was also observed over a several year period. During 20 polar expeditions of the Maria $\mathrm{Cu}-$ rie-Skłodowska University to Spitsbergen the highest average $\left(+6.2^{\circ} \mathrm{C}\right)$ was recorded in 1998, the lowest $\left(+3.0^{\circ} \mathrm{C}\right)$ in 1987 . The average for twenty measurement seasons was calculated at $+5.0^{\circ} \mathrm{C}$. The average daily air temperature also fluctuated in a rather wide range: from $-7.9^{\circ} \mathrm{C}$ in 1987 to $+10.2^{\circ} \mathrm{C}$ in 2002 (Bartoszewski et al. 2006). Precipitation total was the meteorological element characterised by the greatest variability (within the range of about $72 \mathrm{~mm}$ in 1986-2008 period) in the Calypsobyen region. The highest precipitation total $(55.4 \mathrm{~mm})$ was recorded in the melt season (from June to September) of 1994, and in 1993 and 1998 it was zero; the average pre- 


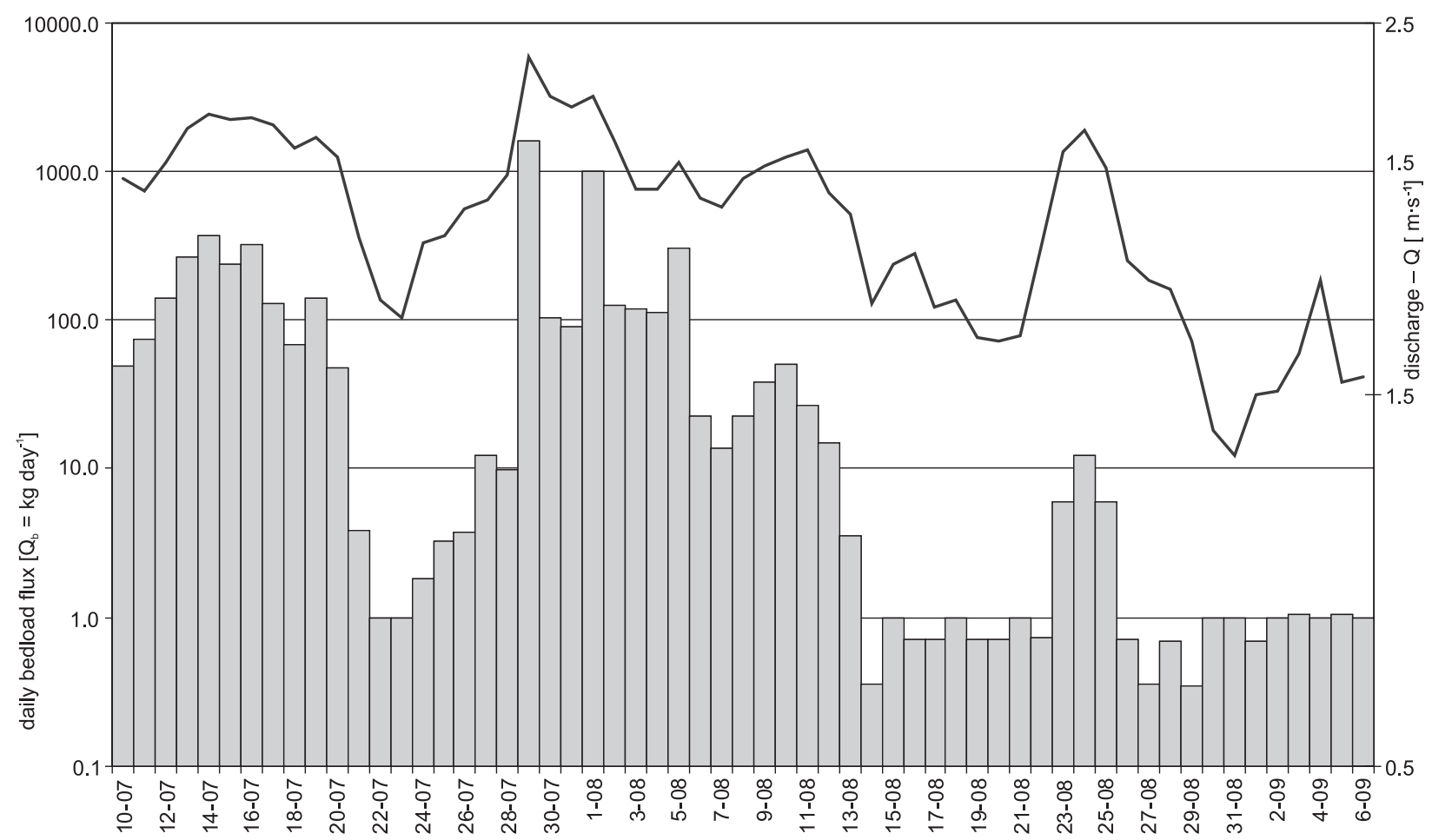

Fig. 5. Total daily bedload flux $\left[\mathrm{Qb}=\mathrm{kg} \mathrm{day}^{-1}\right]$ and mean daily discharge $\left[\mathrm{Q}=\mathrm{m}^{3} \mathrm{~s}^{-1}\right]$ in the Scott River in the melt season of 2009

cipitation total for twenty melt seasons was 17.5 $\mathrm{mm}$. The highest daily total of over $36 \mathrm{~mm}$ was recorded in 1993 (Bartoszewski et al. 2006).

In the melt season of 2009 the course of weather was such as in other years (Fig. 5). Air temperature in the measurement period ranged from $+2.0^{\circ} \mathrm{C}$ to $+7^{\circ} \mathrm{C}$ (variability coefficient was $350 \%$ ) with an average of $+4.9^{\circ} \mathrm{C}$, which was similar to the average value over the 20 year period. The precipitation total in the measurement period (18.1 mm) was slightly higher than that of the 20 year period. During the observed 16 precipitation days the maximum daily total did not exceed 5 $\mathrm{mm}$ and differed considerably from the previously recorded maxima (Bartoszewski et al. 2006).

Mean annual outflow from the Scott River catchment, with a complex supply structure, is about $900 \mathrm{~mm}$, and mean discharge over the 20 year period is estimated at about $900 \mathrm{dcm}^{3} \cdot \mathrm{s}^{-1}$, which corresponds to a specific discharge of 90 $\mathrm{dcm}^{3} \cdot \mathrm{s}^{-1} \cdot \mathrm{km}^{2}$ (Bartoszewski 1996). The Scott River is characterised by highly varying river stages and irregular discharge - daily, seasonal and over the 20 year period of record. The maximum flood discharges caused by the increase in air temperature and/or high precipitation reached
$12 \mathrm{~m}^{3} \cdot \mathrm{s}^{-1}$ (7-9.08.1993 - Bartoszewski 1998). The occurrence of weather extremes can considerably change the outflow conditions in the Spitsbergen glacial catchments in a short time, which is reflected in fluvial transport.

In the melt season of 2009 the water stage in the Scott River channel ranged from 7 to $22 \mathrm{~cm}$. The mean daily discharge (from 1.3 to about 2.4 $\mathrm{m}^{3} \cdot \mathrm{s}^{-1}$ ) was similar to average values (Fig. 5). Both water stages and discharges corresponded well to the run of mean daily air temperature and daily precipitation total. The discharge variability also matches that of the run and intensity of sediment transport, which is rather irregular (Fig. 5).

\section{Results}

The obtained results indicate a great variability of dynamics of bedload transport in the conditions of rather stable discharge: from 1.3 to 2.4 $\mathrm{m}^{3} \cdot \mathrm{s}^{-1}$, with the mean value of $2.0 \mathrm{~m}^{3} \cdot \mathrm{s}^{-1}$, both in daily cycle and in the whole measurement period (Fig. 6). The daily bedload rate in the particular measurement sites ranged from 0 to $220 \mathrm{~kg} \cdot \mathrm{m}^{-1}$. 
day $^{-1}$. Mean daily transport in the particular measurement sites was $4.3,11.9,11.1$ and 15.5 , and the average daily value was $10.7 \mathrm{~kg} \cdot \mathrm{m}^{-1} \cdot$ day $^{-1}$. The maximum daily values (from 138 to $220 \mathrm{~kg} \cdot \mathrm{m}^{-1}$. day $^{-1}$ ) were recorded during the flood on July $29^{\text {th }}$ of 2009. These values constituted from $20 \%$ to $54 \%$ of the total mass measured in the particular measurement sites. The total bedload mass discharged at the particular measurement sites was $255.8,699.9,653.9$ and $917.3 \mathrm{~kg} \cdot \mathrm{m}^{-1} \cdot$ day $^{-1}$ (mean $631.7 \mathrm{~kg} \cdot \mathrm{m}^{-1} \cdot$ day $\left.^{-1}\right)$; therefore, the total bedload discharge in the channel cross-profile can be estimated at (almost $98 \mathrm{~kg}$ day $^{-1}$, i.e. about $5.8 \mathrm{t}$ ) during the measurement period.

Analysis of the daily distribution of the bed load values indicates spatial and temporal differentiation of bedload transport (Fig. 6). The increase in bed load mass in the particular measurement sites from the southern to the northern river-bank (from S1 to S4) was distinctly marked for the whole measurement period. During some days the highest daily loads were alternately measured in the sites located in the thalweg zone (S3 and S4) though the daily maximum load (66 $\mathrm{kg}$ ) was caught in the S2 measurement site. This fact enabled us to conclude that transport routes shift in the channel cross-profile. With respect to bedload transport variability the measurement period was distinctly divided into two parts. In the first half (from July $9^{\text {th }}$ to August $9^{\text {th }}$ of 2009) the elementary rate of bedload transport was considerably more variable over particular sites and days, and was in accordance with the dynamics of discharge changes. In the second half (from August $10^{\text {th }}$ to September $7^{\text {th }}$ of 2009 ) - daily bedloads were usually low and not related to discharge values (Fig. 6). This fact is confirmed by the differentiation of correlation coefficients between the variability of elementary rate of bedload transport and discharge values in two parts of the measurement period (Table 1).

The course of regression curves, indicating weak connection between these elements, is probably conditioned by the occurrence of hysteresis in bedload transport (Richards 1982, Zwoliński 1989). The relation between bedload transport rate and discharge changes was different in two parts of the measurement period due to spatial

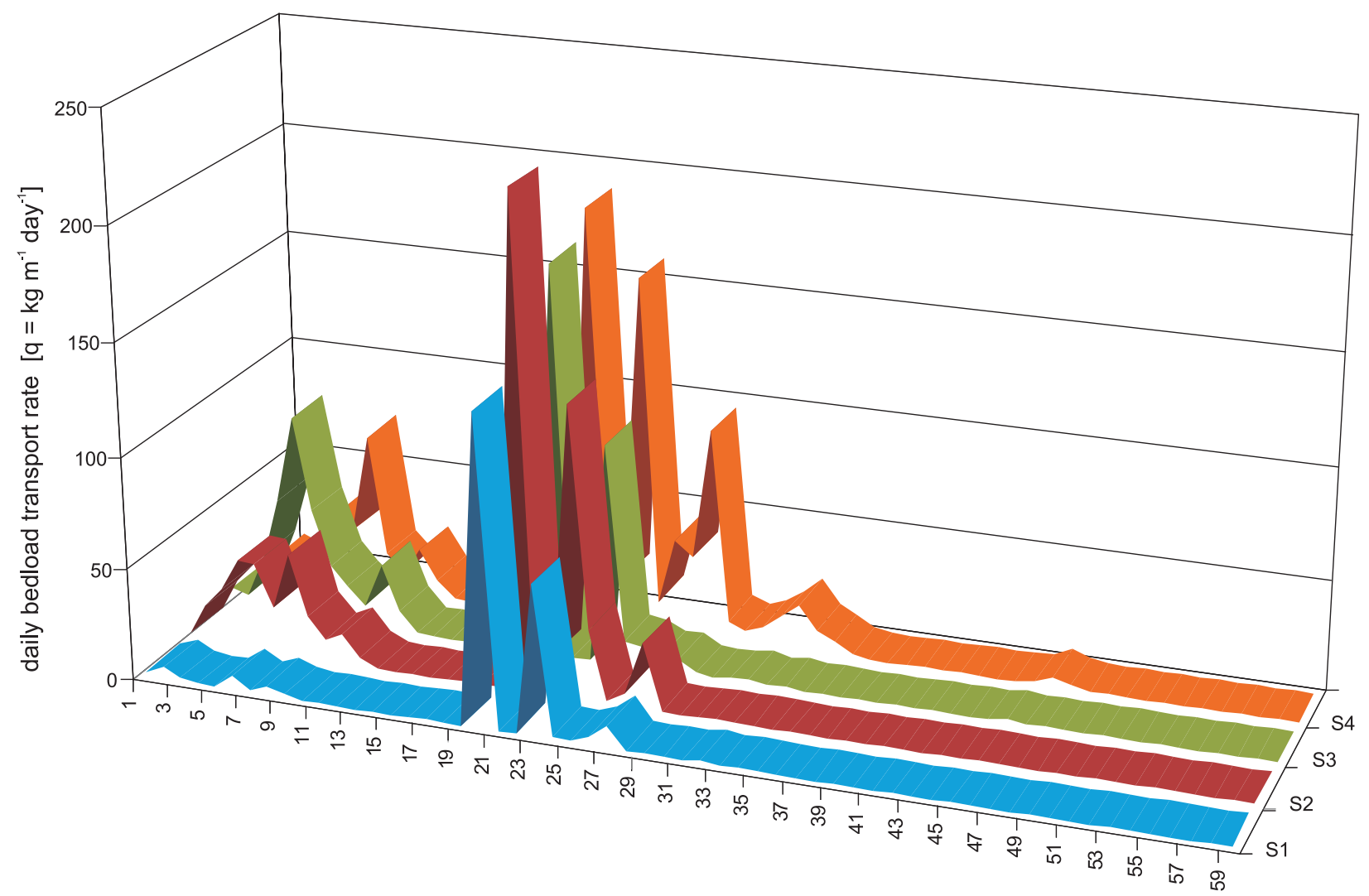

Fig. 6. Daily bedload transport rate $\left[\mathrm{qb}=\mathrm{kg} \cdot \mathrm{m}^{-1} \cdot\right.$ day $\left.^{-1}\right]$ in the particular measurement sites of the Scott River cross-profile in the melt season of 2009 
Table 1. Differentiation of linear correlation coefficients between the bedload transport rate and discharge values in two parts of the measurement period

\begin{tabular}{|c|c|c|c|c|c|}
\hline \multirow{2}{*}{$\begin{array}{c}\text { Measurement } \\
\text { period }\end{array}$} & \multicolumn{4}{|c|}{ Measurement site } & \multirow{2}{*}{ Mean } \\
\cline { 2 - 6 } & S1 & S2 & S3 & S4 & \\
\hline $10.07-09.08 .2009$ & 0.206 & 0.359 & 0.372 & 0.352 & 0.361 \\
\hline $10.08-6.09 .2009$ & 0.291 & 0.400 & 0.382 & 0.314 & 0.342 \\
\hline $10.07-6.09 .2009$ & 0.107 & 0.210 & 0.227 & 0.267 & 0.226 \\
\hline
\end{tabular}

and temporal differentiation of material supply to the channel (slumps). In the first part of the measurement period the channel was supplied with slope material redeposited through snow bank cornices directly to the channel. With the melting of snow patches the mass movement processes were triggered on the southern side of the valley gorge section. This phenomenon resulted in the rather high values of elementary rate of bedload transport in the S1 and S2 measurement sites (Fig. 6). In the second part of the measurement period, with stabilization of the valley sides, the Scott Glacier became the main source of material supply. Generally lower discharge and long distance of transport favoured selective erosion resulting in the formation of channel pavement. For that reason the critical velocity of flow necessary to initiate bed-load movement was higher. This fact resulted in the diametrically different amounts of bed-load transported in successive days though the discharge rate was similar (Fig. 6).

The increased sediment load in river water was accompanied by considerable changes of channel geometry. We registered more intensive down-cutting and processes of lateral and vertical accretion of deposits: formation of bars, gravel shadows, levées and building up of the channel bed.

\section{Conclusions}

The results of investigations conducted in the research profile of the Scott River in the melt season of 2009 indicated high temporal and spatial variability of fluvial processes conditioned by hydro-climatic factors - especially glacier condition and ablation rate, glacier extent in the catchment, thickness of permafrost active layer, weather and thermal conditions - determining the flux. The obtained results evidenced variable dynamics of bedload transport, the amount of which ranged from 0 to $220 \mathrm{~kg} \cdot \mathrm{m}^{-1} \cdot$ day $^{-1}$ in particular measurement sites. Bed-load transport is a clear-cut and quantified criterion for morphodynamic, hydrodynamic and ecological estimation of river conditions. Empirical determination of critical parameters of bedload movement and elementary values of rate and mass of transported sediment is very important for the description of the functioning of river catchment geosystems.

The undertaken investigations enabled us to characterise not only the carrier, i.e. river waters, but also their content, i.e. river sediment, and especially bedload - the main component of fluvial transport in braided rivers. The obtained results supplemented the former knowledge of hydrological conditions with the geomorphological details, which concerned the functioning of fluvial system, the routes and sources of sediment supply to channel, and the balance of material transported from catchment.

\section{Acknowledgements}

This research was supported by the grant Functioning of the channel and slope system of the subpolar zone in the conditions of global climate change financed by Deputy Rector for Scientific Research and International Cooperation of Maria Curie-Skłodowska University. The experimental field study was carried out during XXI Maria Curie-Skłodowska University Polar Expedition. The paper was prepared in the scope of promotion of the project POIG.01.03.02-00-082/10 Providing European patent protection for the device for measuring bedload transport in river beds implemented by MCSU in Lublin, co-financed from the resources of the European Union in the scope of the Operational Programme Innovative Economy, years 2007-2013, Priority 1. Research and development of modern technologies.

\section{References}

Bartoszewski S., 1998. Reżim odptywu rzek Ziemi Wedel Jarlsberga (Spitsbergen). Wyd. UMCS, Lublin.

Bartoszewski S., Chmiel S., Michalczyk Z., 2013. Waters. Hydrography. In: P. Zagórski, M. Harasimiuk, J. Rodzik (eds), The Geographical Environment of NW Part of Wedel Jarlsberg Land (Spitsbergen, Svalbard). Faculty 
of Earth Sciences and Spatial Management Maria Curie-Skłodowska University, Lublin.

Bartoszewski S., Gluza A., Siwek K., 2004. Ablacja lodowcowa i odpływ rzeki Scotta (Spitsbergen) w sezonie letnim 2001. Polish Polar Studies, $30^{\text {th }}$ International Polar Symposium, Gdynia: 29-38.

Bartoszewski S., Gluza A., Siwek K., 2006. Wybrane problemy kształtowania się warunków meteorologicznych i hydrologicznych NW części Ziemi Wedela Jarlsberga (Spitsbergen). In: J. Superson, P. Zagórski (eds), Stan $i$ zmiany środowiska przyrodniczego pótnocno-zachodniej części Ziemi Wedela Jarlsberga (Spitsbergen) w warunkach zmian klimatu i antropopresji. Lublin: 53-60.

Bartoszewski S., Gluza A., Siwek K., Zagórski P., 2007. The functioning of Scott Glacier in conditions of climate global changes. Landform Analysis 5: 5-8.

Beylich A.A., Lamoureux S.F., Decaulne A., Dixon J.C., Orwin J.F., Otto J., Zwolinski, Zb., 2010. Sedimentary fluxes and budgets in changing cold environments: The global IAG/AIG sediment budgets in cold environments (SEDIBUD) programme. Geografiska Annaler, Ser. A: Physical Geography 92(2): 151-153. DOI: 10.1111/J.14680459.2010.00386.X.

Bunte, K., Abt, S.R., 2009. Transport relationships between bedload traps and a 3-inch Helley-Smith sampler in coarse gravel-bed streams and development of adjustment functions. Report submitted to the Federal Interagency Sedimentation Project, Vicksburg, MS.

Bunte, K., Abt, S.R., Potyondy, J.P., Ryan, S.E., 2004. Measurement of coarse gravel and cobble transport using a portable bedload trap. Journal of Hydraulic Engineering 130: 879-893.

Bunte, K., Potyond, J. P., Abt, S., 2003. Sampler size and sampling time affect measured bedload transport rates and particle sizes measured with bedload traps in gravel-bed streams. In: J. Bogen, T. Fergus, D.E. Walling (eds), Erosion and Sediment Transport Measurement in Rivers. Technological and Methodological Advances. IAHS 283: 126-133.

Chmiel S., Bartoszewski S., Gluza A., Siwek K., Zagórski P., 2007. Physicochemical characteristic of land waters in the Bellsund region (Spitsbergen). Landform Analysis 5: 11-13.

Gluza A., Siwek K., 2006. Przebieg warunków pogodowych na stacji w Calypsobyen w sezonie letnim 2005. Problemy Klimatologii Polarnej 16: 139-146.

Hammer K.M., Smith N.D., 1983. Sediment production and transport in proglacial stream: Hilda Glacier, Alberta, Canada. Boreas 12: 91-106.

Kociuba W., Janicki G., 2013. Relief. Fluvial processes. In: P. Zagórski, M. Harasimiuk, J. Rodzik (eds), The Geographical Environment of NW Part of Wedel Jarlsberg Land (Spitsbergen, Svalbard). Faculty of Earth Sciences and Spatial Management Maria Curie-Skłodowska University, Lublin: 192-211.

Kociuba W., Janicki G., Siwek K., 2009. Funcjonowanie subsystemu korytowego zlewni Scotta (Spitsbergen Zachodni). In: Materiaty Ogólnopolskiego Seminarium "Funkcjonowanie geoekosystemów zlewni rzecznych $V$. Rozwój dolin rzecznych w warunkach zmian klimatu i zróżnicowanej antropopresji". UAM Poznań: 80-81.

Kociuba W., Janicki G., Siwek K., 2010. Dynamics of changes the bed load outflow from a small glacial catchment (West Spitsbergen). In: D. de Wrachien, C.A. Brebbia (eds), Monitoring, Simulation, Prevention and Remediation of Dense Debris Flow III. WITPress, Southampton, Boston: 261-270.
Kostrzewski A., Kaniecki A., Kapuściński J., Klimczak R., Stach A., Zwoliński Zb., 1989. The dynamics and rate of denudation of a glaciated and an unglaciated catchments, Central Spitsbergen. Polish Polar Research 10(3): 317-367.

Pękala K., Repelewska-Pękalowa J., 2007. Dynamics of active layer of permafrost. Landform Analysis 5: 168-169.

Pękala K., Repelewska-Pękalowa J., 1990. Relief and stratigraphy of Quaternary deposits in the region of Recherche Fjord and southern Bellsund (Western Spitsbergen). In: Polar Session 'Periglacial phenomena of Western Spitsbergen'. Wyprawy Geograficzne na Spitsbergen, Wyd. UMCS, Lublin: 9-20.

Przybylak R., Araźny A., Gluza A., Hojan M., Migała K., Sikora K., Siwek K., Zwoliński Zb., 2006. Porównanie warunków meteorologicznych na zachodnim wybrzeżu Spitsbergenu w sezonie letnim 2005 r. Problemy Klimatologii Polarnej 16: 125-138.

Rachlewicz G., 2007. Floods in high Arctic Valley systems and their geomorfologic effects (examples from Billefjorden, Central Spitsbergen). Landform Analysis 5: 66-70.

Rachlewicz G., Kostrzewski A., Kasprzak L., Zwoliński Zb., 2007. Funkcjonowanie geoekosystemów glacjalnych i peryglacjalnych $\mathrm{w}$ otoczeniu zatoki Petunia, Środkowy Spitsbergen. In: W. Majewski (ed.), Struktura, ewolucja $i$ dynamika litosfery, kriosfery $i$ biosfery w europejskim sektorze Arktyki oraz w Antarktyce (2004-2007). IGF PAN, Warszawa: 49-52.

Reder J., 2006. Ewolucja stref marginalnych lodowców NW części Ziemi Wedela Jarlsberga. In: Stan i zmiany środowiska przyrodniczego pótnocno-zachodniej części Ziemi Wedela Jarlsberga (Spitsbergen) w warunkach zmian klimatu $i$ antropopresji. Wyd. UMCS, Lublin: 45-51.

Reder J., Zagórski P., 2007. Recession and development of marginal zone of the Scott Glacier. Landform Analysis 5: 175-178.

Repelewska-Pękalowa J., 2004. Dynamika czynnej warstwy zmarzliny w różnych geoekosystemach. In: Z. Michalczyk (ed.), Badania geograficzne w poznawaniu środowiska. Wyd. UMCS, Lublin: 239-245.

Repelewska-Pękalowa J., Pękala K., 2006. Rzeźba peryglacjalna rejonu Bellsundu (Spitsbergen) w aspekcie badań Wypraw Polarnych UMCS. In: J. Superson, P. Zagórski (eds), Stan i zmiany środowiska przyrodniczego pótnocno-zachodniej części Ziemi Wedela Jarlsberga (Spitsbergen) $w$ warunkach zmian klimatu $i$ antropopresji. Wyd. UMCS, Lublin: 25-33.

Richards K.S., 1982. Rivers: form and processes in alluvial channels. Methuen, London.

Superson J., Zagórski P., 2007. Dynamika zmian rzeźby ujściowych odcinków den dolin rzecznych i stożków aluwialnych w rejonie Calypsostrandy (NW część Ziemi Wedela Jarlsberga, Spitsbergen). In: E. Smolska, D. Giriat (eds), Rekonstrukcja dynamiki procesów geomorfologicznych - formy rzeźby i osady. Wyd. UW, Warszawa: 355-366.

Szczęsny R., Dzierżek J., Harasimiuk M., Nitychoruk J., Pękala K., Repelewska-Pękalowa J., 1987. Photogeological map of Renardbreen, Scottbreen and Blomlibreen Forefield (Wedel Jarlsberg Land, Spitsbergen), scale 1:10 000. Wydawnictwa Geologiczne, Warszawa.

Szpikowski J., Szpikowska G., Zwoliński Zb., Rachlewicz G., Kostrzewski A., Marciniak M., Dragon K., 2014. Character and rate of denudation in a High Arctic glacierized catchment (Ebbaelva, Central Spitsbergen). Geomorphology. DOI: 10.1016/j.geomorph.2014.01.012. 
Warburton J., 1990. An alpinie proglacial fluvial sediment budget. Geografiska Annaler 72A: 261-272.

Zagórski P., Siwek K., Gluza. A., Bartoszewski S., 2008. Changes in the extent and geometry of the Scott Glacier, Spitsbergen. Polish Polar Research 29(2): 163-185.

Zwoliński Zb., 1989. Geomorfologiczne dostosowanie się koryta Parsęty do aktualnego reżimu rzecznego. Dokumentacja Geograficzna 3-4.
Zwoliński Zb., Mizgajski, A. Szpikowski J., 2007. Wybrane właściwości morfodynamiczne, sedymentacyjne i hydrochemiczne geoekosystemów zachodniego wybrzeża Zatoki Admiralicji, Wyspa Króla Jerzego. In: W. Majewski (ed.) Struktura, ewolucja i dynamika litosfery, kriosfery i biosfery w europejskim sektorze Arktyki oraz w Antarktyce (2004-2007). IGF PAN, Warszawa: 64-66. 